\title{
Effective utilization of glycerol for the synthesis of 2-methylpyrazine over $\mathrm{ZnO}-\mathrm{ZnCr}_{2} \mathrm{O}_{4}$ catalyst
}

\author{
A VENUGOPAL ${ }^{\mathrm{a}}$, R SARKARI ${ }^{\mathrm{a}}$, S NAVEEN KUMAR ${ }^{\mathrm{a}}$, M KOTESH KUMAR $^{\mathrm{a}}$, \\ S SYED JOHN ${ }^{\mathrm{a}}$, J KRISHNA REDDY ${ }^{\mathrm{a}}$ and A HARI PADMASRI ${ }^{\mathrm{b}, *}$ \\ a Inorganic and Physical Chemistry Division, CSIR-Indian Institute of Chemical Technology, Tarnaka, \\ Hyderabad 500 007, India \\ ${ }^{b}$ Department of Chemistry, University College for Women, Osmania University, Koti, Hyderabad \\ 500 095, India \\ e-mail: akula@iict.res.in; ahpadmasri@gmail.com
}

MS received 5 July 2013; revised 1 January 2014; accepted 2 January 2014

\begin{abstract}
Bioglycerol an inevitable by-product in the production of biodiesel was effectively utilized for the synthesis of 2-methylpyrazine (2-MP) by vapour phase dehydrocyclization with ethylenediamine over $\mathrm{ZnO}$ $\mathrm{ZnCr}_{2} \mathrm{O}_{4}(\mathrm{Zn}-\mathrm{Cr}-\mathrm{O})$ mixed oxides. These $\mathrm{Zn}-\mathrm{Cr}-\mathrm{O}$ samples were obtained from hydrotalcite precursors synthesized by precipitation method at different $\mathrm{pH}(\sim 7$ and 9$)$ and calcination in air at $450^{\circ} \mathrm{C}$. X-ray diffraction (XRD) and Fourier transform infrared (FT-IR) analysis confirmed the presence of $\mathrm{ZnCr}_{2} \mathrm{O}_{4}$ species. Transmission electron microscopy (TEM) images indicated spherical particles with mean diameter of 35.8 and $24 \mathrm{~nm}$ for the $\mathrm{Zn}-\mathrm{Cr}-\mathrm{O}$ prepared at $\mathrm{pH} \sim 7$ and $\sim 9$, respectively. Surface $\mathrm{Zn}$ enrichment was observed in the near-surface region of $\mathrm{Zn}-\mathrm{Cr}-\mathrm{O}$ prepared at $\mathrm{pH} \sim 9$. Differences in dehydrocyclization activity of $\mathrm{Zn}-\mathrm{Cr}-\mathrm{O}$ mixed oxides were established based on spectroscopic data that emphasized changes in structural properties of $\mathrm{Zn}-\mathrm{Cr}-\mathrm{O}$ obtained at different $\mathrm{pH}$.
\end{abstract}

Keywords. Bio-glycerol; 2-methylpyrazine; TEM; FT-IR; ESR; $\mathrm{ZnO}^{-} \mathrm{ZnCr}_{2} \mathrm{O}_{4}$.

\section{Introduction}

Owing to diminution of fossil fuel sources with time, alternative energy resources are becoming increasingly important. In recent times, $\mathrm{R} \& \mathrm{D}$ has focussed on production of alternative fuels from renewable resources such as biomass-derived compounds, particularly biodiesel production from non-edible oils. Bio-diesel is an intriguing candidate because it is renewable, and carbon neutral. ${ }^{1-4} \mathrm{~A}$ major drawback of this process is that about $10 \mathrm{wt} \%$ of bio-glycerol is obtained as a by-product during the process; as a result, surplus of inexpensive glycerol is produced. Hence, the cost of biodiesel is the constraint for commercialization of this product with ever-increasing production of biodiesel. Recovery and effective utilization of such bio-glycerol has been considered as one of the options to lower the overall cost of biodiesel production.

Production of alternative fuels from renewable resources is a crucial task. From an economical and environmental standpoint, utilization or safe disposal of by-products obtained in conversion/transformation of renewable resources is utmost important. Several

\footnotetext{
*For correspondence
}

alternatives are being explored to utilize bio-glycerol, and commercial plants have been established recently to produce propylene glycol from glycerol. Conversion of bio-glycerol into value-added compounds and fine chemicals have been extensively studied by several authors. ${ }^{5}$ One such process is the production of 1,2-propanediol (a key compound in the synthesis of 2-methylpyrazine) by hydrogenolysis of bio-glycerol over supported noble metal catalysts at high pressures. 2-Methyl pyrazine is an intermediate compound for the synthesis of 2-amido pyrazine, a well-known bacteriostatic and antitubercular drug. Conventionally, 2methyl pyrazine is synthesized by dehydrocyclization of ethylenediamine (EDA) and 1,2-propanediol. Forni and Pollesel have studied a Pd-promoted zinc chromite catalyst for the synthesis of 2-methylpyrazine using EDA and 1,2-propanediol. ${ }^{6}$

The present study explores $\mathrm{Zn}-\mathrm{Cr}$ hydrotalcite precursors that have been synthesized at $\mathrm{pH} \sim 7$ and $\sim 9$, and catalytic activities were evaluated for the synthesis of 2-methylpyrazine by dehydrocyclization of EDA and aqueous glycerol. Fresh as well some of the used samples were characterized by BET-surface area, differential thermal and thermogravimetric analysis (DT/TGA), scanning electron microscope energy dispersive X-ray 
analysis (SEM-EDX), power X-ray diffraction analysis (XRD), X-ray photoelectron spectroscopy (XPS), electron spin resonance (ESR), transmission electron microscopy (TEM) and Fourier transformed infrared (FT-IR) spectroscopy.

\section{Experimental}

\subsection{Preparation of catalysts}

The $\mathrm{Zn}-\mathrm{Cr}$ catalysts employed in this investigation were prepared by a simple co-precipitation method using $\mathrm{Zn}\left(\mathrm{NO}_{3}\right)_{2} \cdot 6 \mathrm{H}_{2} \mathrm{O}$ and $\mathrm{Cr}\left(\mathrm{NO}_{3}\right)_{3} \cdot 9 \mathrm{H}_{2} \mathrm{O}$ (SigmaAldrich, AR grade) with $\mathrm{Zn}: \mathrm{Cr}=2: 1$ (mole ratio), in order to obtain hydrotalcite structure. ${ }^{7}$ Samples were prepared at two different $\mathrm{pH}$, i.e., at $\mathrm{pH} 7$ and 9 using a mixture of $2 \mathrm{M} \mathrm{NaOH}+1 \mathrm{M} \mathrm{Na}_{2} \mathrm{CO}_{3}$ (base mixture) as precipitating agent. Gels were washed thoroughly, filtered and oven-dried for $12 \mathrm{~h}$ at $120^{\circ} \mathrm{C}$, and subsequently, calcined in static air at $450^{\circ} \mathrm{C}$ for $5 \mathrm{~h}$. The $\mathrm{Zn}-\mathrm{Cr}$ samples prepared at $\mathrm{pH} \sim 7$ and $\sim 9$ were denoted as ZC7 and ZC9, respectively. The bulk $\mathrm{Cr}_{2} \mathrm{O}_{3}$ catalyst was prepared by precipitation method using $\mathrm{Cr}\left(\mathrm{NO}_{3}\right)_{3} \cdot 9 \mathrm{H}_{2} \mathrm{O}$ (Sigma-Aldrich, AR grade) with similar composition of base mixture used here. All these samples were screened for dehydrocyclization of EDA and aqueous glycerol and some of the samples were characterized by various spectroscopic techniques.

\subsection{Characterization of catalysts}

Surface properties of the $\mathrm{Zn}-\mathrm{Cr}-\mathrm{O}$ samples were measured by $\mathrm{N}_{2}$ adsorption at $-196^{\circ} \mathrm{C}$ in an Autosorb 3000 physical adsorption apparatus. Specific surface areas were calculated applying BET method. Calcined forms of $\mathrm{Zn}-\mathrm{Cr}-\mathrm{O}$ catalysts were characterized by powder XRD analysis using a Rigaku Miniflex X-ray diffractometer using Ni-filtered $\mathrm{Cu} \mathrm{K} \mathrm{K}_{\alpha}$ radiation $(\lambda=$ $0.15406 \mathrm{~nm}$ ) from $2 \theta=20$ to $80^{\circ}$, at a scan rate of $2^{\circ} \mathrm{min}^{-1}$ with beam voltage and beam current of $30 \mathrm{kV}$ and $15 \mathrm{~mA}$, respectively. SEM-EDX analysis was carried out using JEOL-JSM 5600 instrument. For TEM analysis, samples were dispersed in methanol solution and suspended on a 400-mesh; $3.5 \mathrm{~mm}$ diameter $\mathrm{Cu}$ grid and images were taken using JEOL JEM 2010 highresolution transmission electron microscope. XPS patterns were recorded using a Kratos Axis Ultra Imaging $\mathrm{X}$-ray photoelectron spectrometer equipped with $\mathrm{Mg}$ anode and a multichannel detector. Charge referencing was done against adventitious carbon $(\mathrm{C} 1 \mathrm{~s}, 284.8 \mathrm{eV})$. Shirley-type background was subtracted from the signals. Recorded spectra were always fitted using
Gauss-Lorentz curves to determine binding energies of different elements. Infrared spectra were recorded in $\mathrm{KBr}$ pellets using thermo Nicolet Nexus $670 \mathrm{spec}-$ trometer in the region of $4000-400 \mathrm{~cm}^{-1}$. The spectrum obtained after multiple scans was a plot of percentage transmittance against wave number. ESR analysis of $\mathrm{Zn}-\mathrm{Cr}-\mathrm{O}$ samples were performed at room temperature using JEOL/JES-FA200 spectrophotometer by $\mathrm{X}$-band equipment with an operating frequency $v=9.029 \mathrm{GHz}$. DT/TGA of the oven-dried samples were recorded using a Leeds and Northup (USA) unit at a heating rate of $10^{\circ} \mathrm{C} / \mathrm{min}$, ranging from $30^{\circ}$ to $1000^{\circ} \mathrm{C}$ under nitrogen flow.

\subsection{Activity measurements}

Catalytic activities were carried out using -18/+23 sieved (BSS) catalyst particles. Carbon mass balance was done based on the inlet and outlet concentration of the organic moiety. Prior to the reaction, about $0.2 \mathrm{~g}$ of calcined catalyst (sieved particles $-18 /+23$ BSS) was reduced in $5 \% \mathrm{H}_{2}$ (balance $\mathrm{Ar}$ ) at $400^{\circ} \mathrm{C}$ for $5 \mathrm{~h}$. Catalytic activities were measured under strict kinetic control. An aqueous glycerol solution (20 wt $\%$ in $\mathrm{H}_{2} \mathrm{O}$ ) was used with a glycerol to EDA mole ratio of $1: 1$, and a flow rate of the reaction mixture of $5 \mathrm{~mL} \mathrm{~h}^{-1}$, with $\mathrm{N}_{2}$ as the carrier gas at a flow rate of $1800 \mathrm{cc} \mathrm{h}^{-1}$. The reaction mixture contained a glycerol:EDA: $\mathrm{H}_{2} \mathrm{O}: \mathrm{N}_{2}=1: 1: 20.4: 7.4$ mole ratio.

\subsection{Product analysis}

Samples were analysed by gas chromatograph (Shimadzu, GC-17A) via a flame ionization detector (FID) using a ZB-5 capillary column at a ramping rate of $10^{\circ} \mathrm{C} \mathrm{m^{-1 }}$ from $60^{\circ}$ to $280^{\circ} \mathrm{C}$. Mass balance for all the measurements was $>95 \%$. Samples were analysed by GC-MS (QP5050A Shimadzu) using a ZB-5 capillary column with EI mode. Mass spectra confirmed product distribution and corresponding $\mathrm{m} / \mathrm{z}$ values for methylpyrazine: $\mathrm{M}+. m / z: 94,(\mathrm{M}-\mathrm{HCN})$ +. $m / z: 67,\left(\mathrm{M}-\mathrm{CH}_{3} \mathrm{CN}\right)+. m / z: 53,\left(\mathrm{M}-\mathrm{C}_{3} \mathrm{H}_{4} \mathrm{~N}\right)+$. $m / z: 40$; pyrazine: $\mathrm{M}+. m / z: 80,(\mathrm{M}-\mathrm{HCN})+. m / z$ : 53; EDA: $(\mathrm{M}-\mathrm{H})+m / z: 59,\left(\mathrm{M}-\mathrm{NH}_{3}\right)+. m / z: 43$; glycerol: $\left(\mathrm{M}-\mathrm{CH}_{2} \mathrm{OH}\right)+. m / z: 61 ;\left\{\mathrm{M}-\left(\mathrm{CH}_{2} \mathrm{OH}, \mathrm{H}_{2} \mathrm{O}\right)\right\}+$. $m / z: 43 ; 2,5$-dimethylpyrazine: $\mathrm{M}+. \mathrm{m} / z$ : 108; (M$\left.\mathrm{CH}_{3}\right)+. m / z: 93 ;(\mathrm{M}-\mathrm{HCN})+. m / z: 81 ;\left(\mathrm{M}-\mathrm{CH}_{3} \mathrm{CN}\right)+$. $m / z: 67 ;\left(\mathrm{M}-\mathrm{C}_{3} \mathrm{H}_{6} \mathrm{~N}\right)+. m / z: 52 ;\left(\mathrm{M}-\mathrm{C}_{4} \mathrm{H}_{4} \mathrm{~N}\right)+. m / z:$ 42; pyrazinealdehyde: $\mathrm{M}+\mathrm{m} / \mathrm{z}: 108 ;(\mathrm{M}-\mathrm{H})+. \mathrm{m} / \mathrm{z}$ :

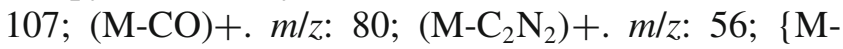
$\left.\left(\mathrm{H}, \mathrm{CO}, \mathrm{C}_{2} \mathrm{H}_{2}\right)\right\}+. m / z: 53$; and 2,3-dimethylpyrazine: $\mathrm{M}+. \mathrm{m} / z: 108 ;\left(\mathrm{M}-\mathrm{CH}_{3} \mathrm{CN}\right)+. \mathrm{m} / z: 67 ;\left(\mathrm{M}-\mathrm{C}_{4} \mathrm{H}_{6} \mathrm{~N}\right)+$. 
$m / z:$ 40. Methylpyrazine was isolated and analysed by ${ }^{1} \mathrm{H}$ NMR spectra which revealed ${ }^{1} \mathrm{H}$ NMR $\left(\mathrm{CDCl}_{3}\right.$,
$200 \mathrm{MHz}): \delta=8.32-8.5(\mathrm{~m}, 3 \mathrm{H}) ; 2.56(\mathrm{~s}, 3 \mathrm{H})$, attributed to methylpyrazine. ${ }^{7}$

$$
\begin{aligned}
& \% \text { Conversion of Ethylenediamine }=\left[\text { moles }_{\text {Ethylenediaminein }}-\text { moles }_{\text {Ethylenediamineout }} / \text { moles }_{\text {Ethylenediaminein }}\right] \times 100 \\
& \% \text { Conversion of Glycerol }=\quad\left[\text { moles }_{\text {Glycerol.in }}-\text { moles }_{\text {Glycerol.out }} / \text { moles }_{\text {Glycerol.in }}\right] \times 100 \\
& \text { Yield }_{2 \mathrm{MP}}=\quad\left[\text { Conversion }_{\text {Glycerol }} \times \text { Selectivity }_{2 \mathrm{MP}}\right] / 100
\end{aligned}
$$

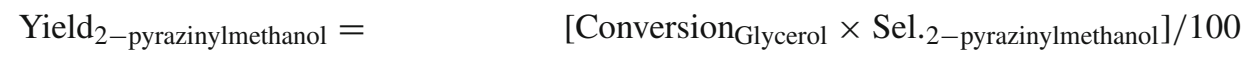

$$
\begin{aligned}
& r_{2 \mathrm{MP}}=\quad\left[\left(\text { Yield }_{2 \mathrm{MP}}\right) \times(\text { Ethylenediamine }+ \text { Glycerol }) \text { flow rate } / S_{\mathrm{BET}}\right. \text { surface area } \\
& \times \text { Weight of the catalyst.] } \\
& r_{2-\text { pyrazinylmethanol }}= \\
& {\left[\left(\text { Yield }_{2-\text { pyrazinylmethanol }}\right) \times(\text { Ethylenediamine }+ \text { Glycerol }) \text { flow rate } / S_{\text {BET surface area }}\right.} \\
& \times \text { Weight of the catalyst] }
\end{aligned}
$$

\section{Results and discussion}

\subsection{Powder XRD analysis}

The XRD patterns of oven-dried samples are reported in figure 1 . The $\mathrm{Zn}-\mathrm{Cr}$ hydrotalcite-like structure is confirmed by presence of HT phase layered double hydroxide ( $\mathrm{LDH}$ ) which is decomposed to form $\mathrm{ZnO}$ and $\mathrm{ZnCr}_{2} \mathrm{O}_{4}$ phases ${ }^{8}$ upon calcination in air at $450^{\circ} \mathrm{C}$ for $5 \mathrm{~h}$. Lattice parameters corresponding to the HT structure are found to be $a=3.10$ and $c=22.5$ for $\mathrm{Zn}-$ $\mathrm{Cr} \mathrm{LDH}$. Basal spacing is calculated from the average of (001) peaks ( $d \sim 0.775 \mathrm{~nm})$, while the ' $a$ ' dimension is calculated as twice the position of the (110) peaks $(a \sim 0.3106 \mathrm{~nm})$. This is in good agreement with literature value. ${ }^{9}$

\subsection{DT/TGA analysis of oven-dried ZC7 and ZC9 samples}

Hydrotalcite-type materials decompose in three consecutive steps, resulting in plateaus in the TGA diagram and endothermic peaks in the DTA pattern. There are three endothermic peaks (figure 2) in the DTA patterns of ZC samples prepared at different $\mathrm{pH}$ levels ( 7 and 9) located at $110^{\circ} \mathrm{C}, 200^{\circ} \mathrm{C}$ and $320^{\circ} \mathrm{C}$. In the TGA analyses, the first stage started as soon as heating commenced, and ceased at $170^{\circ} \mathrm{C}$. The resulting weak and broad endothermic peak is due to the removal of weakly adsorbed water molecules, most likely on the external surface of the particles. The next stage starts immediately upon completion of the first step and results in minima at $200^{\circ} \mathrm{C}$ in DTA pattern and remains up to $250^{\circ} \mathrm{C}$. This peak is possibly due to removal of water of crystallization accompanied with dehydroxylation of hydroxyl groups from brucite-like layered structure. The third and last stage starts with completion of se- cond stage, resulting in an endothermic peak at $320^{\circ} \mathrm{C}$ in the DTA pattern and ceases at $455^{\circ} \mathrm{C}$. This is ascribed to the removal of carbon dioxide from the interlayer
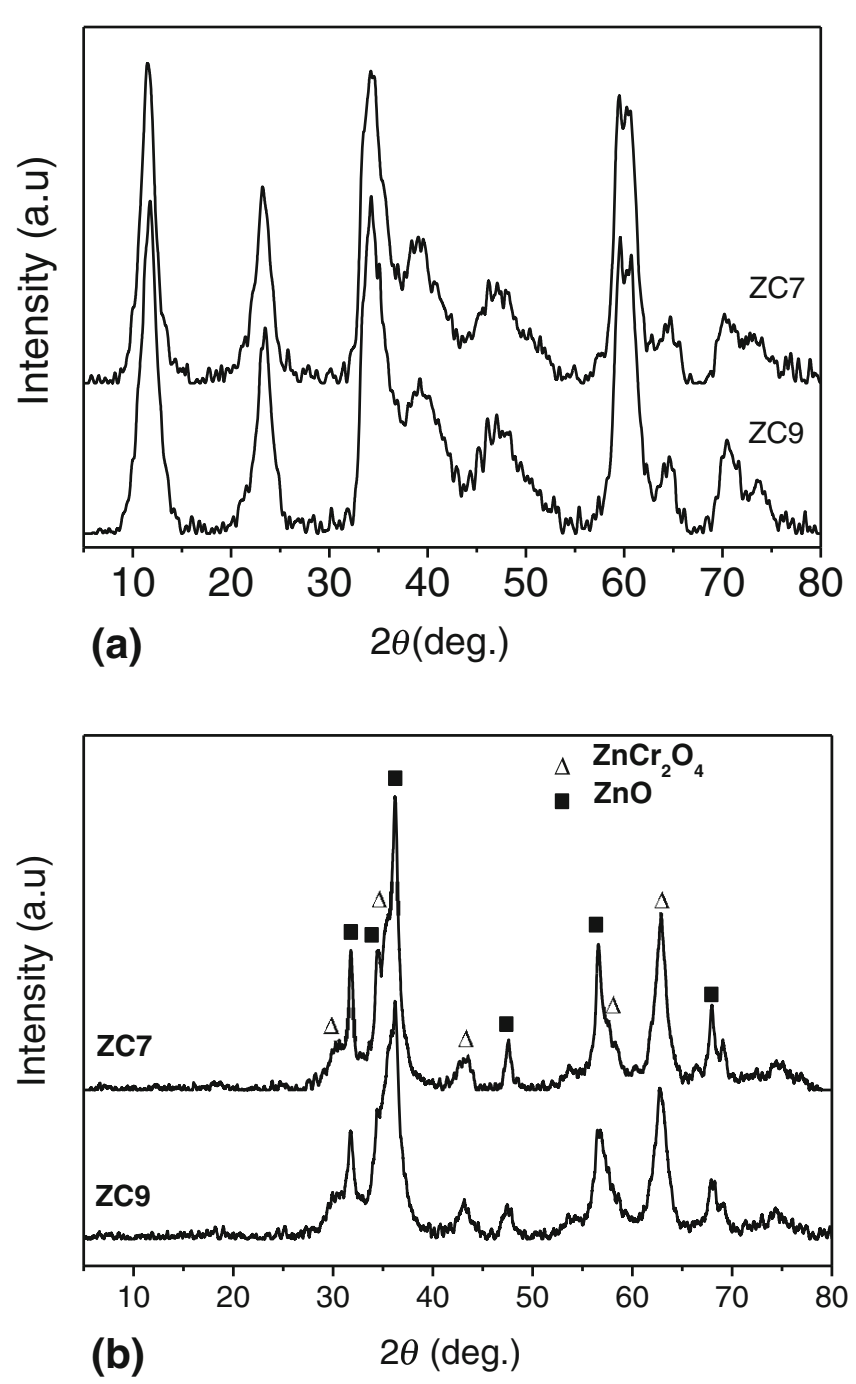

Figure 1. XRD patterns of the (a) oven-dried and (b) calcined ZC7 and ZC9 samples. 


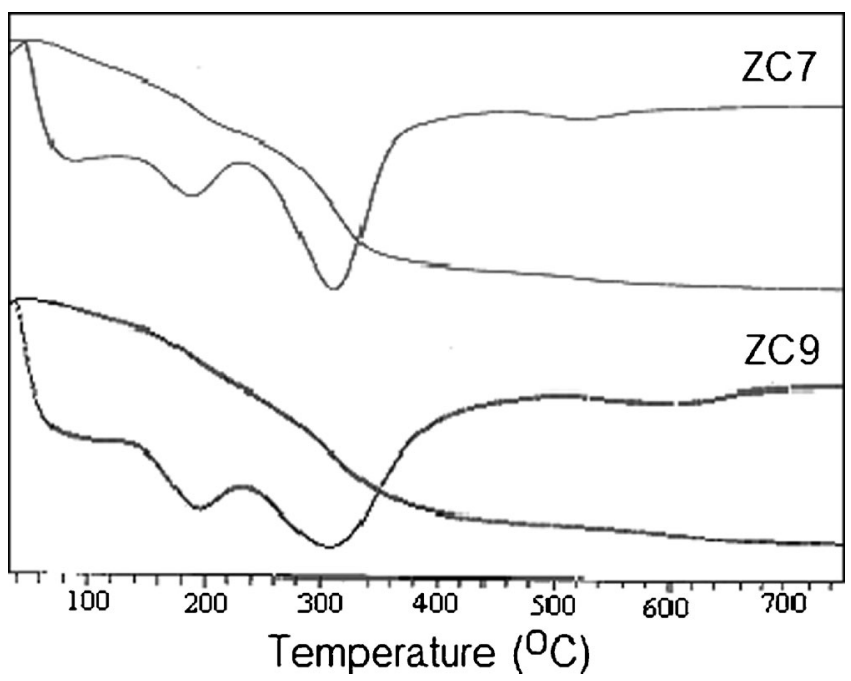

Figure 2. DT/TGA patterns of the oven-dried ZC7 and ZC9 samples.

carbonate anion. In the present investigation, TG analysis of $\mathrm{Zn}$-Cr hydrotalcite precursors revealed that this is responsible for approximately $30 \%$ of the weight loss. End products from this decomposition process are $\mathrm{ZnO}$ and $\mathrm{ZnCr}_{2} \mathrm{O}_{4}$ mixed metal oxides which were identified by powder XRD analysis. ${ }^{7,8}$

\subsection{FT-IR analysis of the calcined $\mathrm{Zn}$-Cr-O samples}

FTIR spectra of calcined catalysts (ZC7 and ZC9) are shown in figure 3 . Absorption band near $3400 \mathrm{~cm}^{-1}$ is due to $\mathrm{O}-\mathrm{H}$ bond vibration modes of hydroxyl groups and water molecules. Absorption band present close to $1629 \mathrm{~cm}^{-1}$ is ascribed to the hydroxyl deformation mode of water. Weak bands near $1496 \mathrm{~cm}^{-1}$ could be

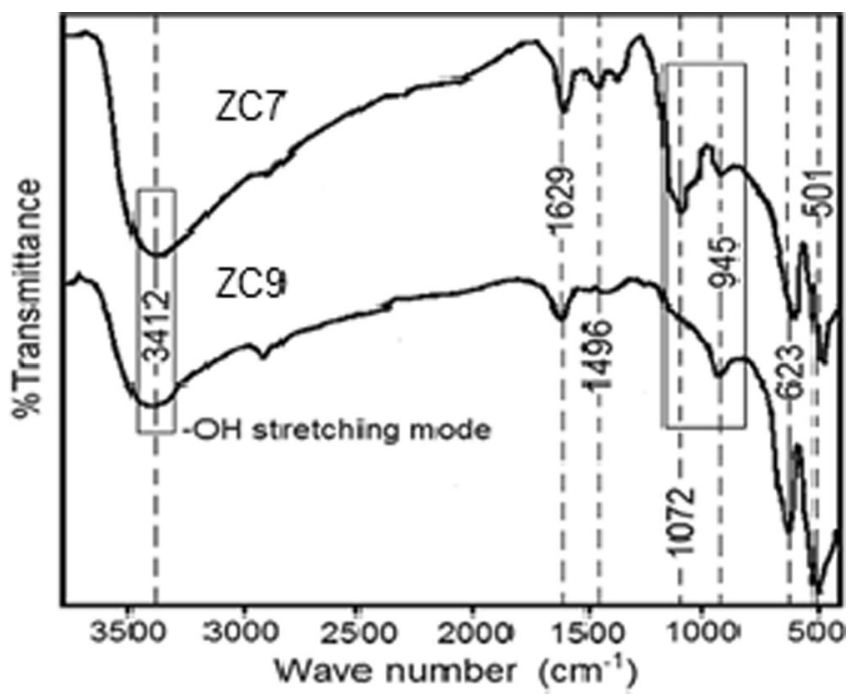

Figure 3. FT-IR spectra of calcined ZC7 and ZC9 catalysts. attributed to carbonate species adsorbed on the external surface of crystallites, observed only in the ZC7 catalyst. Bands below $1000 \mathrm{~cm}^{-1}$ are lattice absorptions due to $\mathrm{Zn}-\mathrm{O}, \mathrm{Cr}-\mathrm{O}, \mathrm{Zn}-\mathrm{O}-\mathrm{Cr}$ vibration modes. IR spectra of spinels are characterized by four bands which originate due to $\mathrm{F}_{1 u}$ symmetry. Shapes and exact positions of high frequency IR bands, $v_{1}$ and $v_{2}$, essentially depend on trivalent cations and thus are related to vibration of lattice octahedral groups. The band recorded at approximately $623 \mathrm{~cm}^{-1}$ in both ZC7 and ZC9 samples is due to the $v_{1}$ mode, and a less sharp band at $501 \mathrm{~cm}^{-1}$ is due to the $v_{2}$ mode of $\mathrm{ZnCr}_{2} \mathrm{O}_{4}$. Bands due to modes $v_{3}$ and $v_{4}$ are not observed, as they are expected between 250 and $150 \mathrm{~cm}^{-1}$. The broad band at $945 \mathrm{~cm}^{-1}$ present in both samples is assigned to a $\mathrm{Zn}-\mathrm{O}$ deformation mode. ${ }^{10,11}$ Appearance of bands in the region of 900 to $1100 \mathrm{~cm}^{-1}$ is an evidence of $\mathrm{M}=\mathrm{O}$ link present in the lattice. ${ }^{12}$

\subsection{TEM analysis of calcined $\mathrm{Zn}$-Cr-O samples}

The TEM images of fresh calcined ZC7 and ZC9 catalysts are displayed in figure 4 . About 20 particles are chosen in order to measure the average particle size of the catalysts. Particles are almost spherical in shape with an average mean particle diameter of 35.8 and $24.0 \mathrm{~nm}$ for (table 1) ZC7 and ZC9 catalysts, respectively. These results suggest that $\mathrm{pH}$ has a significant influence on the synthesis of $\mathrm{Zn}-\mathrm{Cr}$ hydrotalcite precursors that produced $\mathrm{ZnO}-\mathrm{ZnCr}_{2} \mathrm{O}_{4}$ mixed oxide nanoparticles.

\subsection{ESR analysis of the calcined $\mathrm{Zn}$-Cr-O samples}

Figure 5 shows the room temperature ESR spectra of calcined, reduced and used $\mathrm{Cr}_{2} \mathrm{O}_{3}$ and $\mathrm{Zn}-\mathrm{Cr}-\mathrm{O}$ catalysts. Clustered $\mathrm{Cr}^{3+}$ ions of the bulk or $\beta$-phase resonance exhibit a broad, symmetric resonance absorption line with a peak-to-peak line width of $\left(\Delta \mathrm{H}_{\mathrm{pp}}\right)$ of 50 to $300 \mathrm{mT}^{13}$ Oxidized phase of $\mathrm{Cr}_{2} \mathrm{O}_{3}$ usually contains coupled $\mathrm{Cr}^{3+}$ and $\mathrm{Cr}^{6+}$ species only, and these species are highly stable (in the calcination temperature range of $200^{\circ}$ to $600^{\circ} \mathrm{C}$ ) when compared to $\mathrm{Cr}^{3+}$ or $\mathrm{Cr}^{6+}$ species alone. The spectra are broad and symmetrical (figure 5a) and $\Delta H_{\mathrm{pp}}$ is varied (table 1) where ZC7 exhibits a peak-to-peak line width of $161 \mathrm{mT}$ and $130 \mathrm{mT}$ in case of ZC9 catalyst showing differences in structural properties of $\mathrm{ZnO}-\mathrm{ZnCr}_{2} \mathrm{O}_{4}$ mixed oxides synthesized from $\mathrm{Zn}$-Cr hydrotalcite precursors as a result of $\mathrm{pH}$ dependency. A comparative ESR spectrum of bulk $\mathrm{Cr}_{2} \mathrm{O}_{3}$ exhibited a peak-to-peak line width $\left(\Delta H_{\mathrm{pp}}\right)$ of $114 \mathrm{mT}$. Peak widths of the reduced (figure 5b) samples are found to be $\Delta H_{\mathrm{pp}}=44$ and $61 \mathrm{mT}$ for the ZC7 and ZC9 catalysts, respectively. ESR spectra of the used catalysts are reported in 


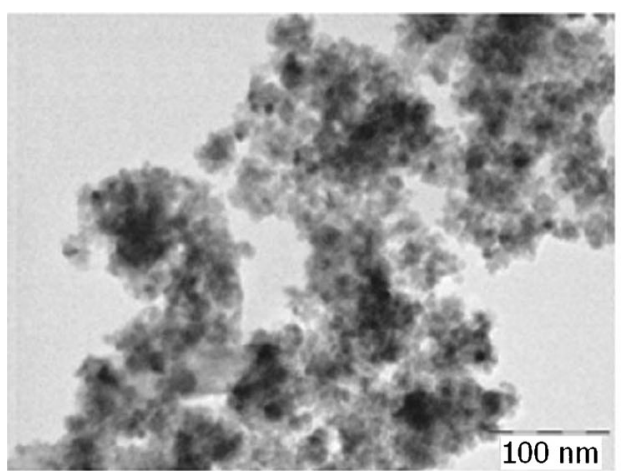

(a)

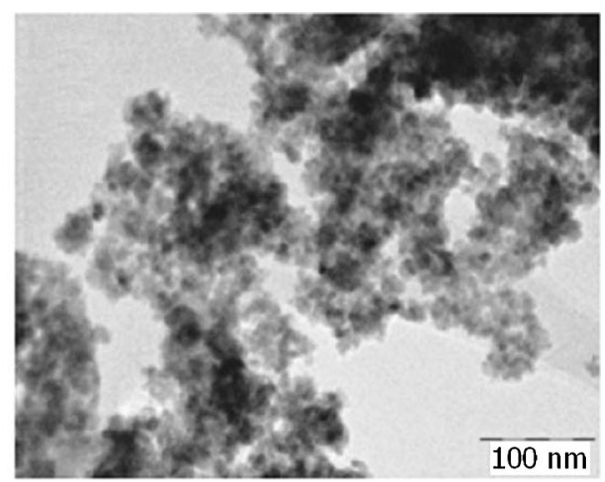

(b)

Figure 4. TEM images of $\mathrm{Zn}-\mathrm{Cr}-\mathrm{O}$ prepared at (a) $\mathrm{pH}=7$ and (b) $\mathrm{pH}=9$.

figure 5c. Line widths show dramatic changes (table 1) when compared to the reduced catalysts. Figure 5c suggests the presence of amorphous carbon for the $\mathrm{Cr}_{2} \mathrm{O}_{3}$ (used) catalyst with $\Delta H_{\mathrm{pp}}=0.88 \mathrm{mT}{ }^{14}$ Decrease in line width of the reduced and used catalysts are probably due to exchange coupling between the $\mathrm{Cr}^{3+}$ ions, which results in an exchange narrowing of the resonance line. Fresh calcined (ZC7 and ZC9) samples show broad symmetric lines with near-Lorentzian shapes, centred at $g=1.98$, characteristic of magnetically interacting $\beta$-phase $\mathrm{Cr}^{3+}$ species. Whereas bulkamorphous chromia displayed a symmetric ESR signal centred at $g=2.242$ with $\Delta H_{\mathrm{pp}}$ of $114 \mathrm{mT}$ is attributed to clustered $\mathrm{Cr}^{3+}$ ions. ${ }^{15} \mathrm{~A}$ significant change is observed in line widths upon treatment with $\mathrm{H}_{2}$ (table 1). Changes in ESR spectral shape could be due to variations in the geometry of the compound. ${ }^{16}$ The $\beta$-phase $\mathrm{Cr}^{3+}$ ESR line width was reported to vary from about 80 to $200 \mathrm{mT}$ with chromia-alumina catalysts reduced in $\mathrm{H}_{2}$ at $500^{\circ} \mathrm{C}^{15}$ Antiferromagnetic $\mathrm{ZnCr}_{2} \mathrm{O}_{4}$ with a normal spinel structure shows line width less than $30 \mathrm{mT}$ broad over the temperature range of $-173^{\circ} \mathrm{C}$ to $23^{\circ} \mathrm{C} .{ }^{17}$ Forni and Oliva have observed the ESR line width ranging between 65 and $39 \mathrm{mT}$ with $\mathrm{ZnO}-\mathrm{ZnCr}_{2} \mathrm{O}_{4}$ catalysts. $^{18}$ The observed results in this investigation are analogous to those reported by Forni and Oliva ${ }^{18}$ The broad line width ESR signals of $\mathrm{ZnO}$ -
$\mathrm{ZnCr}_{2} \mathrm{O}_{4}$ mixed oxides of fresh calcined (ZC7 and ZC9) catalysts could be explained based on strong spin-spin exchange dipolar broadening and the decrease in line widths of the reduced and used ZC7 and ZC9 catalysts are possibly due to spin-spin exchange narrowing. Fresh and reduced ZC7 and ZC9 samples did not show any signals attributed to $\mathrm{Cr}^{5+}$ species.

\subsection{Surface and bulk analysis of Zn-Cr-O samples}

XPS analysis of $\mathrm{Zn}-\mathrm{Cr}-\mathrm{O}$ samples revealed $\mathrm{Zn}$ enrichment at the near-surface region on ZC9 sample (table 2). Surface oxygen density is slightly lower on ZC9 than ZC7 sample. Our earlier investigations of $\mathrm{O}_{2}$ pulse chemisorption studies on $\mathrm{Zn}-\mathrm{Cr}-\mathrm{O}$ further confirmed the relatively high surface oxygen density on $\mathrm{Zn}-\mathrm{Cr}-\mathrm{O}$ that was prepared at lower $\mathrm{pH} \sim 7$. EDX analysis (table 3) showed that the bulk is enriched with chromium than $\mathrm{Zn}$ in ZC7 compared to ZC9 sample. In contrast, a reverse trend is observed in the XPS analysis of ZC7 and ZC9 samples.

\subsection{Dehydrocyclization activity measurements}

Dehydrocyclization activity data on $\mathrm{Zn}-\mathrm{Cr}-\mathrm{O}$ samples is reported in table 4. Rate of 2MP is lower on ZC7 and almost twice on ZC9 sample. Slightly higher rate

Table 1. Bulk and surface compositions and ESR line widths of ZC7 and ZC9 catalysts.

\begin{tabular}{|c|c|c|c|c|c|c|c|}
\hline \multirow[b]{3}{*}{ Sample } & \multirow{2}{*}{\multicolumn{3}{|c|}{ Composition $(\mathrm{Zn} / \mathrm{Cr})$}} & \multicolumn{3}{|c|}{$\mathrm{Cr}^{3+}$ ESR line widths (mT) } & \multirow{3}{*}{$\begin{array}{c}\text { TEM } \\
\text { Mean particle } \\
\text { size }(\mathrm{nm}) \\
\text { Calcined }\end{array}$} \\
\hline & & & & Calcined & Reduced & Used & \\
\hline & Nominal & EDX & XPS & $\Delta H_{\mathrm{pp}}$ & $\Delta H_{\mathrm{pp}}$ & $\Delta H_{\mathrm{pp}}$ & \\
\hline ZC7 & $2: 1$ & 4.7 & 1.59 & 161 & 44 & 34 & 35.8 \\
\hline ZC9 & $2: 1$ & 3.2 & 2.01 & 130 & 61 & 49 & 24.0 \\
\hline $\mathrm{Cr}_{2} \mathrm{O}_{3}$ & - & - & - & 114 & $\overline{0.88}$ & 202 & \\
\hline
\end{tabular}




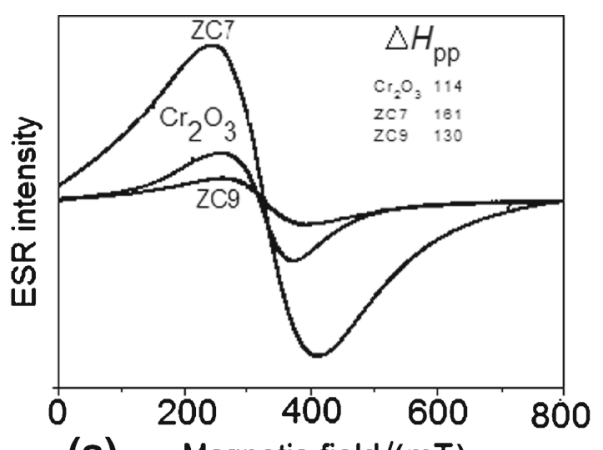

(a) Magnetic field/(mT)

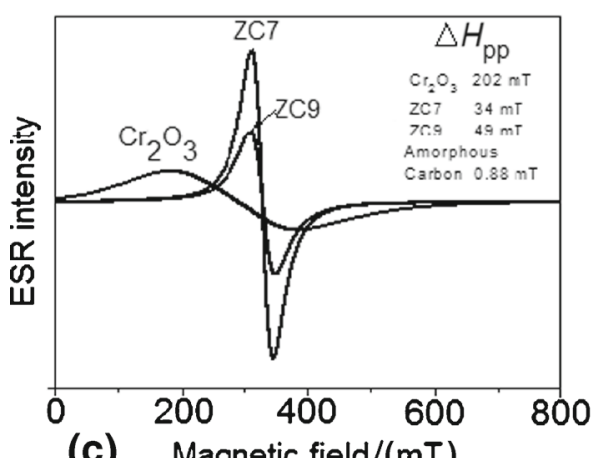

(c) Magnetic field $/(\mathrm{mT})$
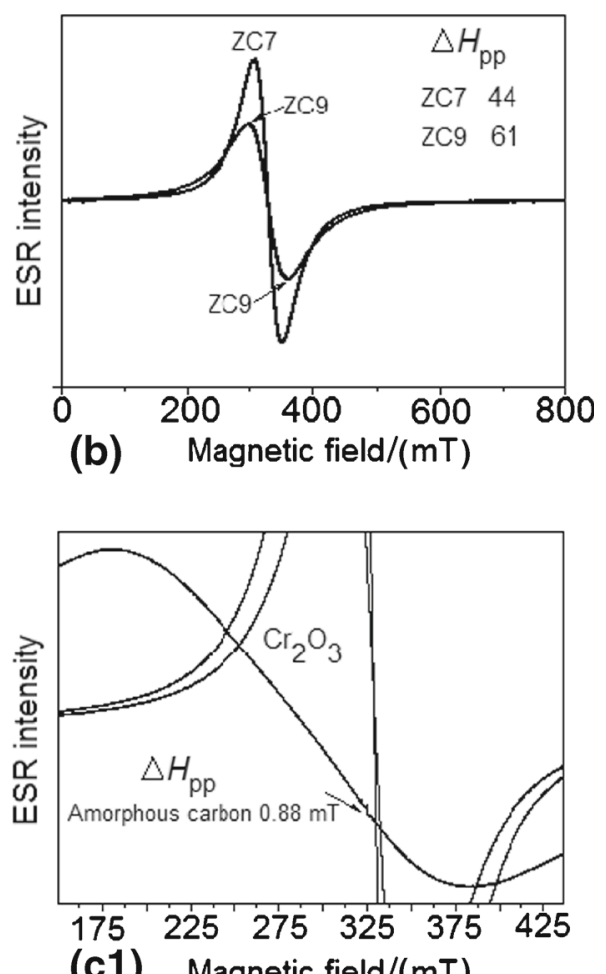

(c1) Magnetic field $/(\mathrm{mT})$

Figure 5. ESR spectra of (a) calcined $\mathrm{Cr}_{2} \mathrm{O}_{3}, \mathrm{ZC} 7$ and $\mathrm{ZC}$, (b) reduced $\mathrm{ZC} 7$ and $\mathrm{ZC} 9$, (c) used $\mathrm{Cr}_{2} \mathrm{O}_{3}, \mathrm{ZC} 7$ and ZC9 catalysts, (c1) Magnification of Figure 5c from 175 to 425 $\mathrm{mT}$.

Table 2. Surface composition obtained from XPS analysis of calcined fresh ZC7 and ZC9 catalysts.

\begin{tabular}{lccccccc}
\hline Catalyst & $\mathrm{Zn}$ & $\mathrm{Cr}$ & $\mathrm{O}$ & $\mathrm{Zn} / \mathrm{Cr}$ & $\mathrm{O} / \mathrm{Zn}$ & $\mathrm{O} / \mathrm{Cr}$ & $\mathrm{O} /(\mathrm{Zn}+\mathrm{Cr})$ \\
\hline ZC7 & 23.37 & 14.68 & 61.95 & 1.59 & 2.65 & 4.22 & 1.63 \\
ZC9 & 30.68 & 15.26 & 54.05 & 2.01 & 1.76 & 3.54 & 1.17 \\
\hline
\end{tabular}

Table 3. Bulk compositions of calcined fresh and used ZC7 and ZC9 catalysts obtained from EDX analysis.

\begin{tabular}{lcccccc}
\hline Catalyst & $\mathrm{Zn}$ & $\mathrm{Cr}$ & $\mathrm{O}$ & $\mathrm{Zn} / \mathrm{Cr}$ & $\mathrm{O} / \mathrm{Zn}$ & $\mathrm{O} / \mathrm{Cr}$ \\
\hline ZC7fresh & 61.58 & 13.08 & 25.34 & 4.7 & 0.41 & 1.93 \\
ZC7used & 62.26 & 13.76 & 23.98 & 4.5 & 0.38 & 1.74 \\
ZC9fresh & 63.01 & 19.56 & 17.43 & 3.2 & 0.27 & 0.89 \\
ZC9used & 63.3 & 18.90 & 17.8 & 3.3 & 0.28 & 0.94 \\
\hline
\end{tabular}

Table 4. Comparison of dehydrocyclization activities at a reaction temperature of $400{ }^{\circ} \mathrm{C}$ over ZC7 and ZC9 catalysts.

\begin{tabular}{lccc}
\hline & \multicolumn{3}{c}{ Specific rate $\left(\mu \mathrm{mol} \mathrm{s}^{-1} \mathrm{~m}^{-2}\right)^{\mathrm{a}}$} \\
\cline { 2 - 4 } Catalyst & 2-Methylpyrazine & 2-Pyrazinylmethanol & Others $^{\mathrm{b}}$ \\
\hline ZC7 & 2.91 & 1.33 & 0.56 \\
ZC9 & 5.89 & 1.73 & 0.45 \\
\hline
\end{tabular}

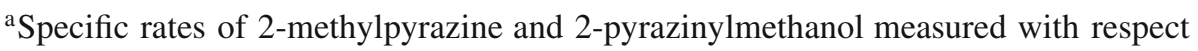
to $2 \mathrm{MP}$ and 2-pyrazinylmethanol yields normalized by $S_{\mathrm{BET}}$

${ }^{\mathrm{b}}$ Others include pyrazine, 2-pyrazinaldehyde and $(-2,6 ;-2,5 ;-2,3)$ -dimethylpyrazines 
of 2-pyrazinylmethanol is observed on ZC9 compared to ZC7. Formation of 2MP occurs by homo-coupling of 2-pyrazinylmethanol which undergoes a cyclic transition state. ${ }^{7}$ A marginal difference is observed in the rate of 2-pyrazinylmethanol over ZC7 and ZC9 compared to the rate of $2 \mathrm{MP}\left({ }^{2 \mathrm{MP}} r_{\mathrm{ZC} 9}{ }^{2 \mathrm{MP}} r_{\mathrm{ZC} 7}=2\right)$ suggesting higher cyclization activity of ZC9 than the ZC7 sample.

\section{Conclusion}

Hydrotalcite precursors of $\mathrm{Zn}-\mathrm{Cr}$ synthesized at $\mathrm{pH}=$ 7 and 9 produced a mixed oxide of $\mathrm{ZnO}-\mathrm{ZnCr}_{2} \mathrm{O}_{4}$ upon calcination in air at $450^{\circ} \mathrm{C}$. XRD and FT-IR analysis of $\mathrm{Zn}-\mathrm{Cr}-\mathrm{O}$ indicated the presence of both $\mathrm{ZnO}$ and $\mathrm{ZnCr}_{2} \mathrm{O}_{4}$ species. Presence of stabilized $\mathrm{Cr}^{3+}$ species in both ZC7 and ZC9 samples was observed in ESR investigations. Decrease in peak to peak width ratio was huge in the case of ZC7 which is attributed to the presence of large size particles. TEM studies revealed the formation of large size particles in $\mathrm{Zn}-\mathrm{Cr}-\mathrm{O}$ obtained at low $\mathrm{pH}$. Compositions obtained from EDX analysis showed chromium enrichment in the bulk of the $\mathrm{Zn}-\mathrm{Cr}$ O sample. In contrast, XPS analysis indicated that $\mathrm{Zn}$ $\mathrm{Cr}-\mathrm{O}$ synthesized at higher $\mathrm{pH}(\sim 9)$ is found to have $\mathrm{Zn}$ enrichment at the near-surface region. High dehydrocyclization activity of $\mathrm{Zn}-\mathrm{Cr}-\mathrm{O}$ synthesized at $\mathrm{pH}=$ 9 was explained as due to small-sized $\mathrm{Zn}-\mathrm{Cr}-\mathrm{O}$ particles and Zn-enriched Zn-Cr-O surface. Finally, it can be concluded that nano-sized mixed oxide $\mathrm{ZnO}-\mathrm{ZnCr}_{2} \mathrm{O}_{4}$ catalyst derived from $\mathrm{HT}$ precursor synthesized at $\mathrm{pH} \sim$ 9 is found to be highly efficient in the conversion of bioglycerol to 2-methylpyrazine. Thus, this process can be extended to utilize bio-glycerol for the industrially important anti-TB drug intermediate.

\section{Acknowledgements}

The authors RS and MKK thank the Council for Scientific and Industrial Research (CSIR), New Delhi and the
University Grants Commission (UGC), New Delhi for the award of fellowship. AV and AHP thank Dr M Lakshmi Kantam and Dr K S Rama Rao for their constant encouragement and help.

\section{References}

1. Klass D L 1998 Biomass for renewable energy, fuels, and chemicals (San Diego: Academic Press) p. 29

2. Ma F and Hanna M A 1999 Bioresour. Technol. 701

3. Serio M D, Tesser R, Pengmei L and Santacesaria E 2008 Energy Fuels 22(1) 207

4. Kulkarni M G, Gopinath R, Meher L C and Dalai A K 2006 Green Chem. 81056

5. Zhou C-H (Clayton), Beltramini J N, Fan Y X and Lu G Q (Max) 2008 Chem. Soc. Rev. 37527

6. Forni L and Pollesel P 1991 J. Catal. 130403

7. Sarkari R, Anjaneyulu Ch, Krishna V, Kishore R, Sudhakar M and Venugopal A 2011 Catal. Commun. 12 1067

8. Venugopal A, Sarkari R, Anjaneyulu Ch, Krishna V and Kotesh Kumar M 2012 Appl. Catal. A: General 441-442 108

9. Kloprogge J T, Hickey L and Frost R L 2005 Mater. Chem. Phys. 8999

10. del Arco M, Rives V, Trujillano R and Malet P 1996 J. Mater Chem. 6(8) 1419

11. Stanojević Z V M, Romčvić N and Stojanović B 2007 J. Eur. Ceram. Soc. 27903

12. Stephen J S and Cruiekshank D J 1970 Acta Cryst. B 26 222

13. Andrew A and Mihajlova D 1973 J. Catal. 30387

14. Venugopal A, Rama Rao K S, Sai Prasad P S and Kanta Rao P 1995 J. Chem. Soc. Chem. Commun. 2377

15. O'Reilly D E and MacIver D S 1962 J. Phys. Chem. 66 276

16. Forni L, Oliva C, Vatti F P, Tugarinov V Y and Vishniakov A V 1993 J. Mater. Sci. 283291

17. Baran M, Piechota S and Pajaczkowska A 1981 Acta. Phys. Polon, Part A $\mathbf{5 9} 47$

18. Forni L and Oliva C 1988 J. Chem. Soc. Faraday Trans. 84(7) 2477 